\title{
THE CHINESE ELECTRICITY INDUSTRY: SUPPLY CAPACITY AND ITS DETERMINANTS WITH REFERENCE TO OECD COUNTRIES
}

\author{
Guy Liu ${ }^{1} \quad$ Liang Zhang
}

\begin{abstract}
The paper takes two-stage estimation to investigate the direct and indirect determinants of the capacity of power supply in China, with reference to OECD countries. In the first stage we investigate the determinants of demand for electric consumption and in the second stage we test the impact of demand for consumption on capacity. Our study shows that the direct impact on capacity growth is mainly of GDP growth which is a China-specific effect, and load factor which is a non-China specific effect. Capacity investment is driven by demand for power relative to the use of existing capacity. Furthermore, power prices and the industrial structure of an economy are the indirect determinant of capacity via their impacts on demand. The industrial structure is particularly strong for affecting power demand in China, since the country has quickened industrialization with more investment in heavy industry that further fuels up demand for power and so capacity.
\end{abstract}

Keywords: Power Supply, China, Energy

${ }^{1}$ The corresponding author: Department of Economics and Finance, School of Social Science, Brunel University, Uxbridge, UB8 3PH, the UK; Email: guy.liu@brunel.ac.uk 


\section{INTRODUCTION}

The aim of this paper is to look at what determines capacity expansion of electric power supply in China where has experienced a tremendous increase in electricity supply over last three decades. In 2008, China's total installed capacity is $803 \mathrm{MW}$, which is around 10 times of the UK and around $70 \%$ of the US according to the International Energy Agency. When compared with 30 years ago, it had only around 72,350 MW, which was about today's capacity in the UK. As can be seen, China's installed capacity has increased by more than 12 times over the past 30 years.

This huge capacity growth has enabled China to serve its growing demand for electric power without a serious problem of supply shortage. Interestingly, the institutional environment of the Chinese power sector has still been under the plan system. One common phenomenon of a plan system is "shortage", but the Chinese plan economy in the power sector doesn't suffer this problem. This distinctive experience of the Chinese system from the conventional wisdom motivates us to understand the issue about what drives the growth of supply of power with respect to capacity in a situation where the sector has been under the reformed plan control. Without doubt, supply always responds to demand at least in the long-run regardless of a plan or market economy. In a market economy, the response of supply to demand is much quick and fast. In contrast, in a plan economy, the pace is slow. But over the last three decades, in particular, since 1992, we have observed a fast pace of response of supply to demand in China's power sector. The growth of GDP as an indication of demand for power has been always responded by growth of electricity available for end users. This response can be illustrated by the link of GDP growth with electric power consumption in Figure 1. In contrast, the link is not shown strongly in the UK in the Figure. This comparison provides an idea that power supply has a stronger relationship with GDP in China than in the UK.

If capacity investment is a long-run commitment for power supply, and power supply is more responsive to GDP, then we expect that GDP growth drives up power supply in the long-run when other factors are given, such as prices and an economic structure. The close link between GDP and electric power in China can alternatively be interpreted as "the power drives GDP", since without electricity China will lose its power to grow the economy. This may be particular true when the structure of the Chinese economy is dominated by its manufacturing industry. Against these two opposite arguments, the paper will start with testing the causality between GDP and power supply for given the electricity price and an economic structure. The latter two elements in relation to power supply will also be investigated with reference to the OECD electric power sector.

Previous studies attempted to estimate the power shortage and surplus of a particular country through identifying the relationship between demand for power consumption and economic growth. Some studies tried to explain the intensity of the energy uses with various factors, such as the structure of an economy (Zhang \& Nie, 2005; Crompton \& Wu, 2005; Zhang \& Sun, 2008), the growth of industry production (Yang \& Zhang, 2007), GDP growth (Shiu \& Lam, 2004; Liao, Fan \& Wei, 2007), and even the change of technology 
(Garbaccio, Ho \& Jorgenson, 1999). Some studies show evidence that the high energy demand of a country could be resulted from its high GDP growth (Li \& Dorian, 1995; Wu \& Li, 1995; Crompton \& Wu, 2005; Rosen and Houser, 2007).

In attempt to understand what determines power generation capacity, Ma, Oxley and Gibson (2009) looked at the issue through comparing the growth of the capacity with the aggregate demand for power in China, and the paper argued that the energy demand in China can be affected by "the rapid income growth", "the expanding transportation", "the lagged electricity price reform" and etc., while the energy supply can be affected by "the increasing investment", "the improved energy efficiency", "the energy reforms" and etc.. Furthermore, Wen, Wu and Ni (2004) appointed that "the prices of electricity to reflect short-term supply and demand status will create market signal for a proper capacity expansion”. Tishler, Milstein, Woo (2008) investigated "the interdependence among equilibrium capacity, market price level, market price volatility, and supply shortage due to the price capping". With the Israel data, they argued that price capping would lead to power shortages, "because the tightening of the price cap induces an increase in the quantity demanded which is higher than the increase in the optimal capacity". Some other studies even employed the real option theory to explain the optimal investment strategy of different types of power plants (Suzuki and Takizawa, 2004; Gollier, Proult, Thais, Walgenwitz, 2005; Botterud \& Korpas, 2007; Fleten, Maribu, and Wangensteen, 2007).

Those studies provide helpful ground to understand what affects capacity. In line of their studies, one augment of this paper is to look at electric power generation capacity and its determinants through a comparative approach. This approach will enable us to identify which effects are internationally generalized or non-country-specific and which effects are only country-specific. On this regards, the determinants of power supply capacity will be looked at on the basis of using a comparative analysis of China with OECD experience, which can helps identify non-China-specific and China specific effects, respectively. Furthermore, we also intend to identify the elements in terms of direct and indirect impacts respectively on supply. The impact on the capacity of power supply will be assessed first by looking at the explanation of our proposed elements to demand for electricity consumption, and then the elements directly related to consumption will be further investigated for their possible impact on power supply in the long run - capacity growth. If the elements have a significant impact both on demand and on supply, we then call it a direct effect on supply. Otherwise, if the impact is not identified on supply but on demand, then we call it an indirect effect on supply because the impact is made via an effect on demand. In this sense, our strategy to investigate determinants of the capacity of power supply is a two-stage approach. The stage one is to estimate the determinants of power consumption, and the stage two is to verify these demand-related determinants for their possible impact directly on capacity. Any elements that explain directly demand for power consumption but may not directly impact the capacity of power supply are called "indirect determinants" since these indirect determinants affect power supply through their impact on demand for power consumption. 
With the two-stage strategy, the pursuit of our research will be made as follows. Next section will discuss possible determinants of demand for power consumption and supply. Then in section 3, our estimation method and data used for verifying our arguments will be highlighted. The estimated results will be discussed in section 4. We will conclude our analysis and discussion in the last section.

\section{MAJOR ELEMENTS IN RELATION TO POWER CONSUMPTION AND SUPPLY: AN ILLUSTRATION OF CHINA WITH REFERENCE TO OECD COUNTRIES}

\subsection{Economic development and power consumption}

China's economy is characterized by its high GDP growth. For the past 30 years, China's real GDP increased by around 15 times, with an average growth rate of $10 \%$. In contrast, our selected Six OECD countries for this study only achieved relatively moderate economic growth over the past two decades, where the average annual growth of the real GDP of France, Germany, Italy, Japan, the UK and the US was $1.88 \%, 1.73 \%, 1.34 \%, 1.39 \%, 2.51 \%$ and $2.93 \%$ respectively.

In 2007, the total observed net power consumption in China is up to 2,814,663 GWh, i.e. almost equal to the aggregated usage in France, Germany, Italy, Japan and the UK, or $72 \%$ of power consumption in the US. Even back to 1990, China was the third largest power consumer in the world, next to the US and Japan, where its annual net consumption was only $534,890 \mathrm{GWh}$, i.e. around $70 \%$ of Japan and $20 \%$ of the US. Obviously, the power demand in China has increased dramatically for the last two decades.

From 1990 to 2007, the average annual growth rate of the net power consumption in China was at around $10 \%$. In recent years, the average annual growth even reached to $14.55 \%$ from 2002 to 2007 . By contrast, the power consumption of the six OECD countries only increased by no more than $10 \%$ during the same period, with an average annual growth of less than $1.9 \%$.

As shown in Figure 1, we can easily find that both the power consumption and the real GDP have increased dramatically during the past two decades. From 1991 to 2007, the annual growth of both power consumption and the real GDP are at some $10 \%$ in China. In contrast, the relationship between power consumption and GDP in the UK has become weaker and weaker since 1997, where power consumption growth tends to be less linked with GDP growth. 
Figure 1 the real GDP growth and demand for power consumption in China and UK (1990 - 2006)

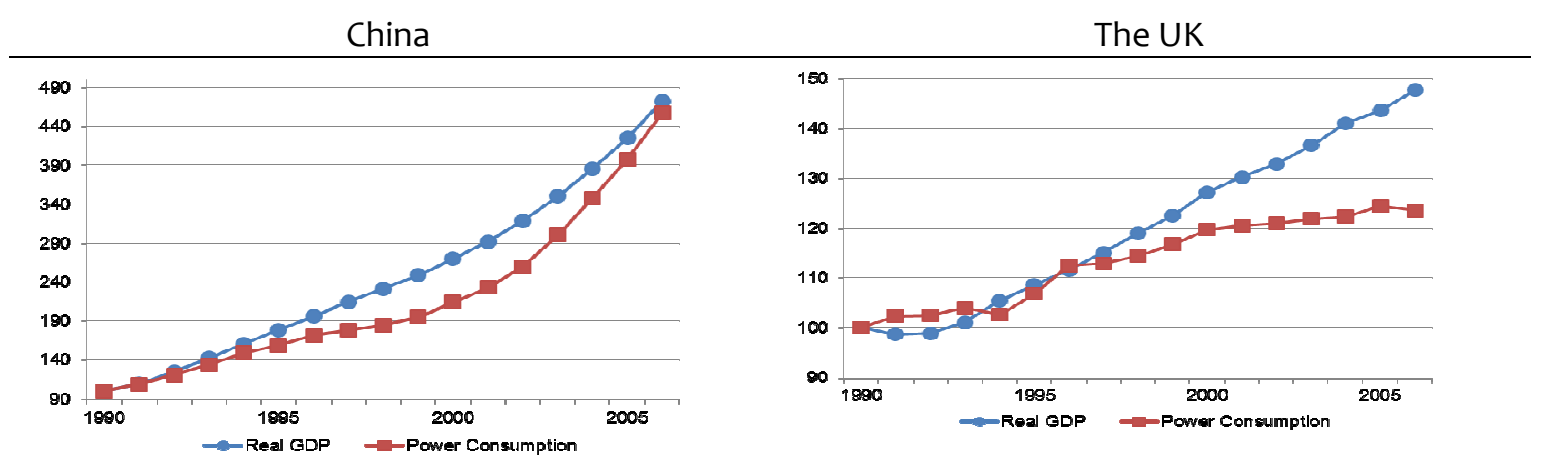

Source: UNdata, International Energy Agency, and the National Bureau of Statistics of China

According to Figure 2, it clearly shows that the Chinese power consumption fluctuated closely with its real GDP. During the early 1990s, the growth of the real GDP is around $12 \%$ and the power consumption growth is around 15\% in China. From 1996 to 2001, the average annual growth of the real GDP and power consumption in China dropped to around $8.6 \%$ and $7.2 \%$, respectively. After that, the pace of the Chinese growth for both GDP and power consumption was accelerated again. In contrast, according to Figure 2, the UK shows a different situation, where power consumption has been quite unlinked with GDP growth. One message from Figure 1 and 2 is that GDP and power consumption are positively linked in the long run and the short run respectively in China, while this relationship appears weak or insignificant in the UK and some other OECD countries. This suggests that the GDP-and-power-demand relationship is China-specific, and it cannot be generalized without an analysis to other economies.

Figure 2 The growth of the real GDP and power consumption in China and the UK(1991 - 2007)

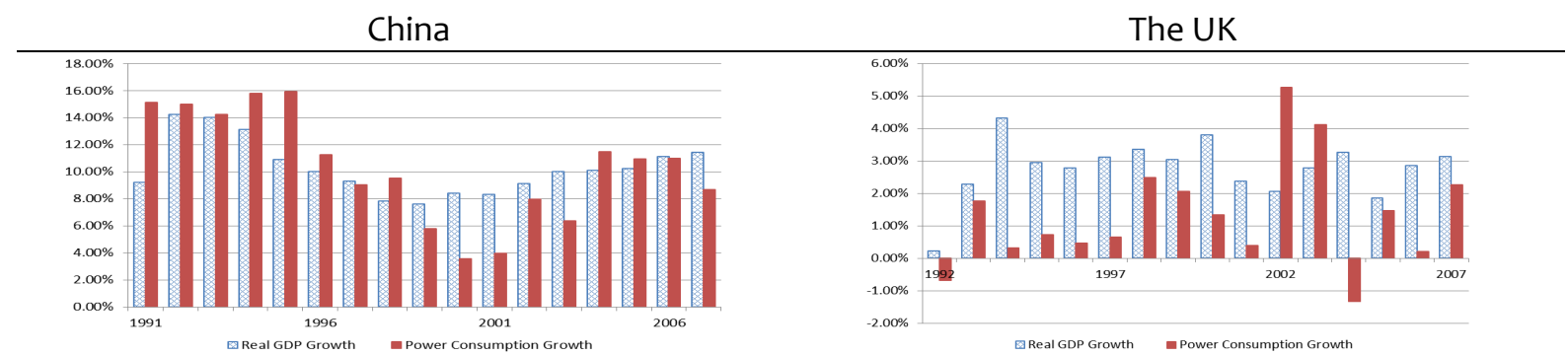

Source: UNdata, International Energy Agency, and the National Bureau of Statistics of China

In 2007 , China consumed $35.73 \%$ of the global electricity generated, but it only contributes $5.9 \%$ of the total GDP in the world. This implies that China's ability in using the power to generate the economic wealth is very low. This may reflect a problem in Chinese economic structure or institution in promoting the efficiency of power usage for production. In Table 1, the electricity intensity is calculated from dividing the electricity consumption by the real GDP. The lower electricity intensity indicates low power consumption required to produce one dollar of GDP. 
Table 1 Power intensity of electricity consumption per GDP (kWh/USD): China and OECD countries

\begin{tabular}{cccccccc}
\hline & China & France & Germany & Italy & Japan & UK & US \\
\hline 1990 & 1.3224 & 0.2598 & 0.2806 & 0.1930 & 0.2514 & 0.2856 & 0.4712 \\
1991 & 1.3158 & 0.2759 & 0.2670 & 0.1944 & 0.2508 & 0.2961 & 0.4967 \\
1992 & 1.2786 & 0.2793 & 0.2583 & 0.1967 & 0.2504 & 0.2961 & 0.4826 \\
1993 & 1.2444 & 0.2821 & 0.2556 & 0.1992 & 0.2519 & 0.2938 & 0.4860 \\
1994 & 1.2267 & 0.2815 & 0.2479 & 0.2015 & 0.2657 & 0.2778 & 0.4803 \\
1995 & 1.1763 & 0.2791 & 0.2472 & 0.2016 & 0.2673 & 0.2810 & 0.4820 \\
1996 & 1.1547 & 0.2883 & 0.2485 & 0.2023 & 0.2664 & 0.2878 & 0.4772 \\
1997 & 1.0985 & 0.2801 & 0.2457 & 0.2047 & 0.2681 & 0.2802 & 0.4635 \\
1998 & 1.0552 & 0.2789 & 0.2431 & 0.2075 & 0.2754 & 0.2748 & 0.4587 \\
1999 & 1.0375 & 0.2753 & 0.2399 & 0.2087 & 0.2817 & 0.2721 & 0.4502 \\
2000 & 1.0481 & 0.2710 & 0.2375 & 0.2105 & 0.2798 & 0.2687 & 0.4505 \\
2001 & 1.0554 & 0.2733 & 0.2399 & 0.2114 & 0.2744 & 0.2642 & 0.4427 \\
2002 & 1.0761 & 0.2694 & 0.2459 & 0.2147 & 0.2782 & 0.2601 & 0.4451 \\
2003 & 1.1342 & 0.2775 & 0.2484 & 0.2211 & 0.2723 & 0.2549 & 0.4378 \\
2004 & 1.1927 & 0.2781 & 0.2490 & 0.2219 & 0.2725 & 0.2476 & 0.4286 \\
2005 & 1.2365 & 0.2748 & 0.2477 & 0.2256 & 0.2716 & 0.2474 & 0.4265 \\
2006 & 1.2800 & 0.2666 & 0.2427 & 0.2270 & 0.2662 & 0.2389 & 0.4152 \\
2007 & 1.3226 & 0.2629 & 0.2372 & 0.2247 & 0.2685 & 0.2312 & 0.4174 \\
\hline Changes & $-20.19 \%$ & $5.21 \%$ & $-14.51 \%$ & $9.50 \%$ & $9.14 \%$ & $-7.50 \%$ & $-6.05 \%$ \\
\hline Changes2002-2007 & $22.91 \%$ & $-2.43 \%$ & $-3.52 \%$ & $4.67 \%$ & $-3.49 \%$ & $-11.10 \%$ & $-6.23 \%$ \\
\hline
\end{tabular}

Source: Based on the information from the Electricity Information 2009 (IEA) and the UN data.

Not surprisingly, China's electricity intensity is the highest among the seven countries. In 2007, China's electricity intensity equals to 3.17 times of the US, 4.93 times of Japan, 5.72 times of the UK and 5.89 times of Italy. It obviously shows that China has a lot to improve when compared with developed countries. It also implies that China has massive energy-intensive industries to produce little but consume more of power. Moreover, such problem became even worsen in recent years. From 1990 to 2001, the electricity intensity in China was decreased by 20.19\%, which was the sign of improvement of the energy efficiency. But, from 2002 to 2007, China's electricity intensity increased by $22.91 \%$. It made the overall electric power intensity of China almost unchanged over the past 20 years.

In contrast, the overall electricity intensity of France, Italy and Japan also increased by $1.19 \%$, $16.42 \%$, and $6.78 \%$ respectively in the period from 1990 to 2007, although France and Japan dropped the intensity by $2.43 \%$ and $3.49 \%$ respectively after 2002 . The best performing economies in lowering the intensity have been Germany, the UK and the US, which have experienced continuous improvement of the electricity intensity since 1990, where the intensity of the three countries dropped by $15.44 \%, 19.05 \%$ and $11.41 \%$ respectively. This implies that most OECD 
countries have reached a stage of development with a low-energy-intensity structure of the economy in the recent years.

\subsection{Economic structure and demand for power consumption}

The structure of an economy is referred to the importance of manufacturing industrial production in the economy. Figure 3 indicates that manufacturing output relative to GDP grows closely with power consumption in China, but this close relationship is not observed in the UK. From 1971 to 2006, the output of China's industrial sector increased by around 23 times, from $42.15 \%$ of GDP in 1971 to $48.50 \%$ in 2007. This increase has been mainly driven by a rapid growth of China's heavy industry, for instance, the heavy industry increased its output relative to the total industry from $58 \%$ in 1999 to $70 \%$ in 2007 , see Table 2.

Figure 3 The power consumption and industrial outputs in GDP: China and the UK (1981-2006)

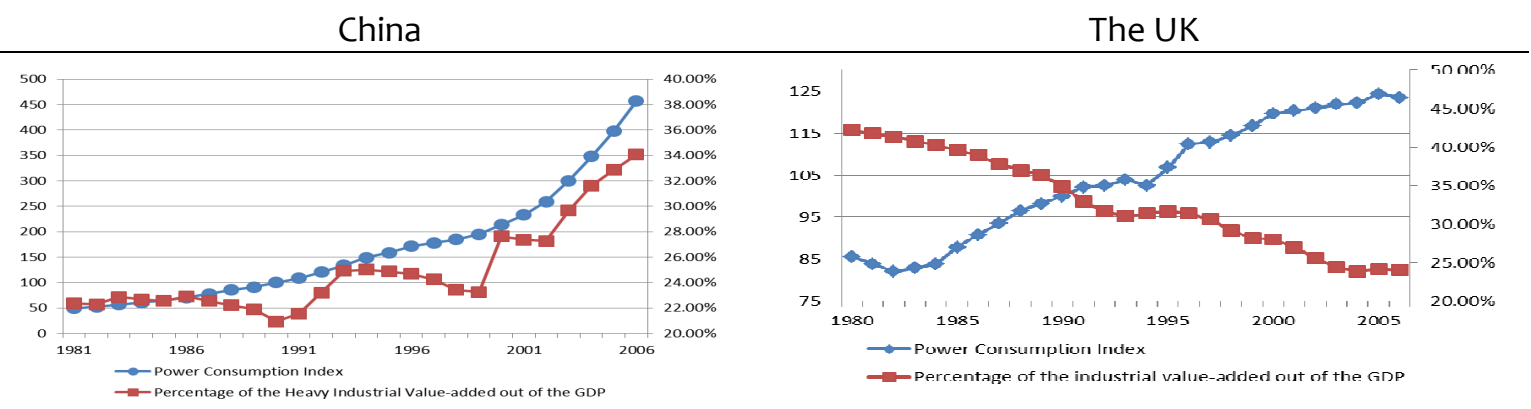

Source: UNdata, International Energy Agency, and the National Bureau of Statistics of China

Table 2 Changes in importance of industrial outputs by light and heavy sector in China over 1999 to 2007

\begin{tabular}{|c|c|c|c|c|c|c|c|c|c|}
\hline & 1999 & 2000 & 2001 & 2002 & 2003 & 2004 & 2005 & 2006 & 2007 \\
\hline Light Industry & $41.97 \%$ & $39.80 \%$ & $39.43 \%$ & $39.14 \%$ & $35.49 \%$ & $33.47 \%$ & $32.44 \%$ & $29.96 \%$ & $29.53 \%$ \\
\hline Heavy Industry & $58.03 \%$ & $60.20 \%$ & $60.57 \%$ & $60.86 \%$ & $64.51 \%$ & $66.53 \%$ & $67.56 \%$ & $70.04 \%$ & $70.47 \%$ \\
\hline Total & $100 \%$ & $100 \%$ & $100 \%$ & $100 \%$ & $100 \%$ & $100 \%$ & $100 \%$ & $100 \%$ & $100 \%$ \\
\hline
\end{tabular}

Source: National Statistics Bureau of China

In contrast, the six OECD countries have experienced the process of "deindustrialization" of the manufacturing sector over the past three decades, where the industrial outputs increased not only slowly but also losing its importance of its output share in the economy. For example, the UK's industrial sector only increased by 1.26 times from 1971 to 2006, and lost almost its share in GDP by $20 \%$ over the same period. By the end of 2007, the industrial sector of all of the six OECD countries falls to the level below $31 \%$ of the total GDP. For example, in the UK, the industrial sector contributes only $23 \%$ of the value-added output to its total GDP in 2007. The decline in the industry suggests that, unlike China, demand for power consumption is no longer related to the manufacturing industry very much but related to consumption of households and the service sector in developed economies, such as the UK, see Table 3. The impact of the service-sector growth on electricity consumption is also seen for China, 
Italy, Japan, the US and France, see Table 3. The Table reports industrial output relative to GDP and its corresponding electricity consumption for China and other major OECD countries, respectively. In 2007, China's industrial usage of electricity accounts for over $75 \%$ of the overall power supplied, much higher than any other six OECD countries. By contrast, industrial users in the US only consumed $24 \%$ of the total electricity generated in 2007. The evidence provide us with support to argue that the economic structure of the service sector matters for power consumption more than the manufacturing industry except China where the heavy industry grows more and more for its importance in the manufacturing and the economy.

Interestingly, given a change of the Chinese industry for its output rising from 42\% of GDP in 1990 to $49 \%$ in 2007, the power consumption of the industry in the total remains almost unchanged over the same time period, see Table 3. This decoupling demand for power consumption with the growth of industrial output indicates a role of production technology in affecting demand for electricity. For instance, technology improvement is evident by the Chinese steel sector and cement \& glass manufacturing sector. The production of one ton of steel fell from using $847 \mathrm{kWh}$ of electricity in 2000 to $719 \mathrm{kWh}$ in 2006. The same was true for the production of cement $\&$ glass that experienced a fall in power usage by some 20\% between 2000 and 2006, see Figure 4. The evidence suggests that technology improvement has helped the Chinese industry reduce its electricity intensity, achieving energy saving while output increased.

Technology improvement reduces power consumption but the growth of output volume brings up industrial demand for electricity. Due to these two counter effects, for the industry as whole, its growth of total power consumption with industrial output will not be clearly cut, depending on which effect is more dominated: technology improvement or volume of production. An increase in volume is certainly expected to boost more demand for power consumption.

In China, the volume is accountable for increasing power consumption in the heavy industry when it experienced a rapid increase from 58\% in total industrial output to 70\% over the period of 7 years for 1999 to 2007 (see table 2). This indicates that the Chinese industry has been experiencing a change from lightproduction technology with low-energy-intensity to heavy-production technology with high-energyintensity as a result of shifting the world heavy industry via restructuring of production from the West to the East. One result of this change is to strengthen the positive relationship of industrial output with demand for power consumption in China, because of a rapid rise in the volume brought by more heavyindustry development.

Because of the concentration of the industrial development on heavy industry, the heavy industrial output of China increased dramatically along with its power consumed. For example, in 2006, China produced over $33 \%$ of iron \& steel in the world, by consuming around $31 \%$ of the global power supplied for 
the iron \& steel production. In the same year, China also produced $48 \%$ of the cement $\&$ glass in the world, by using $41 \%$ of the global power used for the cement \& glass production.

When compared with China, those six OECD countries declined their shares in the global heavy industrial outputs. For example, the UK produced $1.79 \%$ of the global iron \& steel output in 2000 , and its global share dropped to $1.11 \%$ in 2006.

Generally speaking, the industrial sector is so critical to China's economy, China needs much more electric power than any other developed countries to support its industrialization and development of the heavy industry. This industrial development policy can inevitably lead the structure of the Chinese economy to strongly affect demand for power consumption.

In contrast, the service \& commercial usages and the residential usages of electricity only take up very limited percentage in total power consumption in China. In 2007, the commercial and the household consumption only took up around $9 \%$ and $11 \%$ of the total consumption in China. In terms of the OECD countries, the commercial and the household users consumed much more power than in China. For example, in 2007 , the commercial users and the household users consumed $28 \%$ and $34 \%$ of the total power supply in the UK. Besides, the percentage of the industrial demand for power consumption has been decreasing while the commercial and household consumption has increased in the OECD countries.

From the discussion above, it is clear that a change in the Chinese economic structure can bring a positive impact on demand for power consumption, in which this impact is unique to some extent, since this relationship is hardly observed in some "de-industrialized" OECD countries.

\subsection{Electricity prices, power consumption and capacity}

Having discussed economic growth and structure in relation to power consumption, this section will look at how prices can impact on demand for power. In China, as previous studies have identified, there are two prices that can be expected to influence power supply and consumption. One is called the on-grid price which is the price given to Chinese electric power-generating firms to sell their output. Another is the catalogue price that is used by end-users to pay their electricity bills.

From Table 4, we find that although both the catalogue price and the end-user price increased by around $30 \%$ from 2000 to 2009, the two prices could fluctuate in different way in each year. For example, in 2004, the catalogue price increased by around 5.41\%, while the on-grid prices dropped by $-1.55 \%$. As both the two prices are regulated via plan by the state, there is no direct link of changes between two prices annually. 
Table 3 Composition of the GDP and the power consumption by type of users

\begin{tabular}{|c|c|c|c|c|c|c|}
\hline \multirow[t]{2}{*}{ Industry } & \multicolumn{3}{|c|}{$\begin{array}{l}\text { \% of the industrial sector } \\
\text { out of the GDP }\end{array}$} & \multicolumn{3}{|c|}{$\begin{array}{l}\% \text { of industrial usage } \\
\text { out of the total power consumption }\end{array}$} \\
\hline & 1990 & 2000 & 2007 & 1990 & 2000 & 2007 \\
\hline China (Overall Industry) & $41 \%$ & $46 \%$ & $49 \%$ & $78 \%$ & $72 \%$ & $75 \%$ \\
\hline China (Heavy Industry) & $21 \%$ & $28 \%$ & $35 \%$ & $50 \%$ & $45 \%$ & $45 \%$ \\
\hline France & $27 \%$ & $23 \%$ & $21 \%$ & $35 \%$ & $33 \%$ & $30 \%$ \\
\hline Germany & $37 \%$ & $30 \%$ & $30 \%$ & $45 \%$ & $42 \%$ & $45 \%$ \\
\hline Italy & $32 \%$ & $28 \%$ & $27 \%$ & $51 \%$ & $51 \%$ & $46 \%$ \\
\hline Japan & $40 \%$ & $32 \%$ & $30 \%$ & $44 \%$ & $38 \%$ & $33 \%$ \\
\hline UK & $35 \%$ & $28 \%$ & $24 \%$ & $35 \%$ & $34 \%$ & $34 \%$ \\
\hline US & $28 \%$ & $24 \%$ & $22 \%$ & $32 \%$ & $32 \%$ & $24 \%$ \\
\hline \multirow[t]{2}{*}{ Service \& Commerce } & \multicolumn{3}{|c|}{$\begin{array}{l}\text { \% of the service \& commercial } \\
\text { sector } \\
\text { out of the GDP }\end{array}$} & \multicolumn{3}{|c|}{$\begin{array}{l}\% \text { of service and commercial usage } \\
\text { out of the total power consumption }\end{array}$} \\
\hline & 1990 & 2000 & 2007 & 1990 & 2000 & 2007 \\
\hline China & $32 \%$ & $39 \%$ & $40 \%$ & $4 \%$ & $8 \%$ & $9 \%$ \\
\hline France & $70 \%$ & $74 \%$ & $77 \%$ & $25 \%$ & $25 \%$ & $29 \%$ \\
\hline Germany & $61 \%$ & $68 \%$ & $69 \%$ & $17 \%$ & $24 \%$ & $22 \%$ \\
\hline Italy & $64 \%$ & $69 \%$ & $71 \%$ & $18 \%$ & $20 \%$ & $25 \%$ \\
\hline Japan & $58 \%$ & $66 \%$ & $68 \%$ & $28 \%$ & $32 \%$ & $35 \%$ \\
\hline UK & $63 \%$ & $71 \%$ & $75 \%$ & $25 \%$ & $27 \%$ & $28 \%$ \\
\hline US & $70 \%$ & $75 \%$ & $77 \%$ & $31 \%$ & $32 \%$ & $34 \%$ \\
\hline \multirow[t]{2}{*}{ Household } & \multicolumn{3}{|c|}{$\begin{array}{l}\text { \% of the household consumption } \\
\text { out of the GDP }\end{array}$} & \multicolumn{3}{|c|}{$\begin{array}{l}\text { \% of the household usage } \\
\text { out of total power consumption }\end{array}$} \\
\hline & 1990 & 2000 & 2007 & 1990 & 2000 & 2007 \\
\hline China & $49 \%$ & $42 \%$ & $37 \%$ & $8 \%$ & $12 \%$ & $11 \%$ \\
\hline France & $57 \%$ & $56 \%$ & $58 \%$ & $30 \%$ & $31 \%$ & $33 \%$ \\
\hline Germany & $58 \%$ & $58 \%$ & $55 \%$ & $28 \%$ & $26 \%$ & $26 \%$ \\
\hline Italy & $57 \%$ & $58 \%$ & $57 \%$ & $24 \%$ & $22 \%$ & $21 \%$ \\
\hline Japan & $53 \%$ & $54 \%$ & $52 \%$ & $24 \%$ & $27 \%$ & $28 \%$ \\
\hline UK & $62 \%$ & $64 \%$ & $65 \%$ & $33 \%$ & $33 \%$ & $34 \%$ \\
\hline US & $67 \%$ & $68 \%$ & $71 \%$ & $34 \%$ & $33 \%$ & $36 \%$ \\
\hline \multirow[t]{2}{*}{ Agriculture } & \multicolumn{3}{|c|}{$\begin{array}{l}\text { \% of the Agriculture } \\
\text { out of the GDP }\end{array}$} & \multicolumn{3}{|c|}{$\begin{array}{l}\text { \% of the Agricultural usage } \\
\text { out of total power consumption }\end{array}$} \\
\hline & 1990 & 2000 & 2007 & 1990 & 2000 & 2007 \\
\hline China & $27.00 \%$ & $15.00 \%$ & $11.00 \%$ & $6.85 \%$ & $5.00 \%$ & $3.00 \%$ \\
\hline France & $3.77 \%$ & $2.84 \%$ & $2.20 \%$ & $0.65 \%$ & $0.66 \%$ & $0.71 \%$ \\
\hline Germany & $1.49 \%$ & $1.26 \%$ & $0.92 \%$ & $1.50 \%$ & $1.50 \%$ & $1.55 \%$ \\
\hline Italy & $3.49 \%$ & $2.80 \%$ & $2.04 \%$ & $1.93 \%$ & $1.76 \%$ & $1.77 \%$ \\
\hline Japan & $2.59 \%$ & $1.77 \%$ & $1.47 \%$ & $0.22 \%$ & $0.17 \%$ & $0.09 \%$ \\
\hline UK & $1.89 \%$ & $1.04 \%$ & $0.94 \%$ & $1.35 \%$ & $1.28 \%$ & $1.09 \%$ \\
\hline US & $2.06 \%$ & $1.23 \%$ & $1.08 \%$ & $\mathrm{~N} / \mathrm{A}$ & N/A & N/A \\
\hline
\end{tabular}

Source: The National Bureau of Statistics of China, Electricity Information 2009 (IEA) and UN data. 
Table 4 The catalogue price (end price) and on-grid price in China

\begin{tabular}{|c|c|c|c|}
\hline & $\begin{array}{c}\text { End Price } \\
\text { (Yuan/MWh) }\end{array}$ & $\begin{array}{l}\text { On-grid Price } \\
\text { (Yuan/MWh) }\end{array}$ & $\%$ of On-grid Price out of End Price \\
\hline 2000 & 405.0 & 282.0 & $69.63 \%$ \\
\hline 2001 & 407.5 & 281.0 & $68.96 \%$ \\
\hline 2002 & 410.0 & 290.0 & $70.73 \%$ \\
\hline 2003 & 434.7 & 308.5 & $70.96 \%$ \\
\hline 2004 & 458.2 & 303.7 & $66.27 \%$ \\
\hline 2005 & 485.0 & 317.9 & $65.56 \%$ \\
\hline 2006 & 499.0 & 331.0 & $66.33 \%$ \\
\hline 2007 & 514.1 & 336.8 & $65.51 \%$ \\
\hline 2008 & 523.5 & $347 \cdot 3$ & $66.35 \%$ \\
\hline 2009 & 534.3 & 367.6 & $68.80 \%$ \\
\hline Average & 467.1 & 316.6 & $67.77 \%$ \\
\hline
\end{tabular}

In Figure 4, it shows that a change in catalogue electricity prices against power consumption. It indicates that the end users have been in general responsive negatively to a rise in the electricity price. This evidence demonstrates that aggregate demand for power is responsive to prices in line with economic rationale even when electricity prices are planned.

Figure 4. Growth of Catalogue Price(end price), Power Consumption, and Supply Capacity of China 80-06
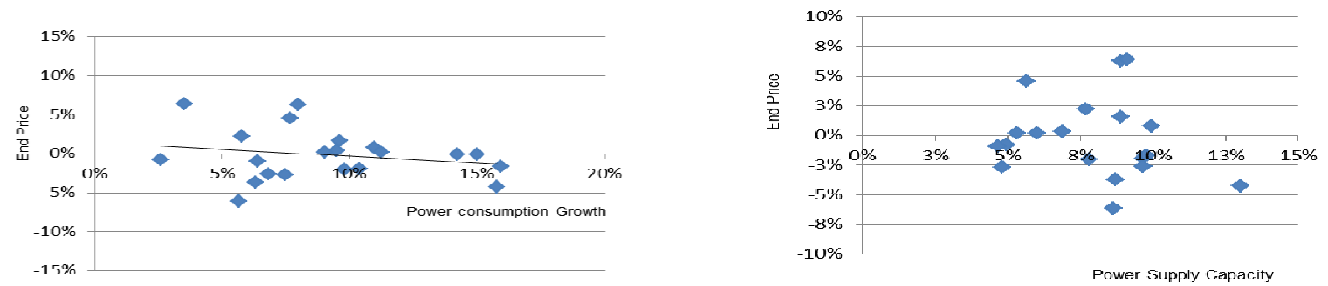

Source: the National Bureau of Statistics of China

The impact of the electricity price on the capacity is not clear in China. The power firms are in favor of high prices for selling their output. Kroeber (2008) pointed out that "the simply raising end-user electricity prices would merely spur the construction of more un-needed generating capacity." However, the more complicated thing is that a rise in the end-user price may not be fully passed back to the producers since the Grid company is the 'middle man' between power producers and consumers. As the price is nontransmittable between producers and consumers it can reduce the effect of the user price as an incentive to stimulate directly power producers to increase their capacity and so outputs.

The Chinese government regulates both end-user and on-gird prices, respectively. It is expected that ongird prices will more directly stimulate capacity investment and outputs since the prices are the sales price 
of the firm. For the same analogy, the change in the grid price may not be transmitted to the end users to affect final demand directly because of 'the middle man' of the Grid Company. The government also plans output for each firm that can produce during a year for given its capacity. Market entry or investment remains open. Therefore, the firm has to expand its capacity in order to gain more output quota from the state. This mixed market and plan institution gives an expectation that the firm shall respond to at least a rise in grid prices for capacity expansion which is long run commitment for production of output.

In contrast, in the West, Wolak and Patrick (1996) found that the major generators in the UK could increase their profits by unilaterally restricting the amount of generation capacity available for the market. Such argument is also supported by the study on the California electricity market by Borenstein and Bushnell (1999). Their observation shows that the monopolist firm can use capacity to change prices in the power supply. If this is established, then what we can observe is a negative relationship between capacity and the price, and the high price is due to less capacity available for production.

In short, in the West, if producers gain a market power, we may see less capacity available with the higher price. In China, the producers have no market power as prices are all planned by the state, and consumers face one planned price that may affect their consumption decision in response to a given price by the state. We expect that consumers are economically rational. The price paid by the consumers may not affect the firm in choosing capacity and output since the consumer-paid price is separated from the sales price of the firm. Thus, the impact of the consumer-paid price is expected to be weak on supply but strong on demand.

\subsection{Response of supply capacity to consumption}

In the past two decades, China achieved a dramatic expansion of the power generation capacity. From 1991 to 2008 , the average annual growth of the power capacity in China is as high as $10.36 \%$. In 1990 , the total capacity in China was only equal to $18.8 \%$ of the US. After rapid expansion for two decades, the generation capacity is increased by 5.8 times during the period from 1990 to 2008. In 2007, China's installed capacity is equal to $65.5 \%$ of the US, and almost equal to the sum of the total capacity of France, Germany, Italy, Japan and the UK.

In line with the capacity surge in China, according to Figure 5, power consumption has also increased as same as capacity by around 4.5 times over the last two decades. In contrast, in France for instance, the net capacity increased only by some $12 \%$, when compared the domestic power consumption that was increased by around $38 \%$ over the same decades. 
Figure 5 The capacity growth and demand for power consumption of China and France $1990-06$
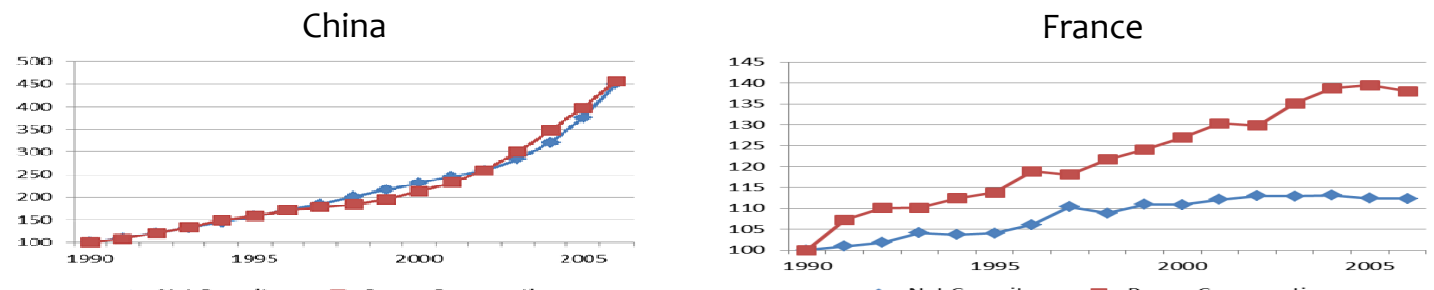

Source: International Energy Agency and the National Bureau of Statistics of China

The comparison above indicates that power capacity and demand for consumption are in general related closely with each other, but the strength of the relationship can vary. The high demand will always stimulate more investment in capacity. But this view may not be agreed by every existing study. Kroeber (2008) argues against this expectation since its study showed an example that Jiangsu Province in China has huge demand for power as it is one of the Chinese industrial bases but the power producing capability is lower. The decoupling between demand for power and capacity of power supply demonstrates a case that demand and the capacity of supply is not always closely correlated with each other for various reasons.

One reason is that the structural delinking and another is the load factor. The structure delinking means that the capability of power generation is located differently from consumption, such as 'the coal-rich northern provinces of China' that supplies electricity are away from non-resourceful regions where demand is high there. This creates the structural delinking between supply and demand in terms of a geographical dimension.

The delinking can also be observed in some regions in OECD. For instance, more than 16\% of power supplied come from imports in Italy where its local capacity of supply has been always short for many years. This shortage of local supply is because imported electricity is cheaper. Therefore, the local investment in capacity is delinked to growth of demand due to market open for competition in the EU electricity market.

Furthermore, the growth of capacity can be less responsive to demand due to a load factor that indicates a degree of capacity utilization over a period. It is expected that capacity will not be expanded in response to a change in demand if the power industry or a firm has a low rate of capacity utilization or a low load factor. This is also a case of Italy with the lowest load factor of $38 \%$ in EU in 2007 according IEA report in the year. This further explains why the capacity and demand for consumption is delinked significantly in Italy. In contrast, in 2007, the average rate of the load factor in China was around 52\%, higher than Japan (47.2\%) and the US (45\%), but lower than France (55.8\%), Germany (54.8\%) and the UK (53.7\%). 
The point of the above is that the growth of capacity may not closely respond to demand for consumption if there is the structure delinking due to market open for competition of supply or the load factor is generally lower in a region.

\section{DATA AND METHOD}

\subsection{Estimation Models}

To verify statistically in what we discussed in the last section on the issues related to the determination of capacity, we take a two-stage estimation approach to identify both the direct and indirect factors which could explain significantly an impact on the aggregate capacity expansion of power plants in China with reference to other six OECD countries. In the first stage, estimation is pursued for identifying the factors that can affect the power consumption in terms of both the long and short term, respectively. An increase in power consumption is expected to be responded by power generators in committing more investment to increase supply in the long run, which is capacity investment. To test this expectation, in the second stage, our estimation then focuses on examining the demand-driving variables for their impact on capacity expansion at an aggregate level of a market or nation. The variables in our estimation of the capacity are derived from our supply capacity function that includes demand for power consumption and the load factor as two basic elements. We also estimate the supply function by replacing the power consumption variable with its determinants identified in the stage one of estimation of demand, in which the estimation has real GDP, electricity prices for end users, and the power exported. This extension enables us to identify which determinants of demand can also impact on supply directly. In order to make an international comparison, our econometric models are estimated with reference to the six OECD countries, respectively.

Stage 1:

Rosen and Houser (2007) classified the driver of the total energy demand in China according to "the industry-led demand" and "the consumption-driven demand" elements. They argued that as China is making high energy-intensive industrial products rather than importing, it would raise its energy consumption. This argument is consistent with our expectation discussed in the last section of this paper that GDP as an aggregate output of a nation, together with the price of power and economic structure, are expected to affect demand for power, in which this can be written as:

$C=f(G D P, p, y)$

Where $C$ is the aggregated level of demand for power consumption, $p$ is the electricity price for the endusers, and y represents an economic structure. This is a demand function with the expectation that both GDP and the structure of an economy will play a positive role in stimulating demand but the price will be opposite. The demand for power function will be estimated in stage 1 in aim of identifying the factors that 
affect the power consumption both in the long term and in the short term, respectively. So, two separate demand functions are specified as follows.

Model $1 a-$ demand function with long-run relationship

$C_{t}=\alpha+\beta_{1} G D P_{t-1}+\beta_{2} p_{t-1}+\beta_{3} y_{t}+\gamma_{t} D_{t}+\varepsilon_{t}$

where $C_{t}$ is the growth of demand for power consumption at period $t$; $G D P_{t-1}$ is the growth of the real GDP in period $t-1 ; p_{t-1}$ is the index of the price of the electricity for the end users; $y$ denotes the percentage of the industrial output measured by value added in GDP, or the share of heavy industry in the GDP, as a proxy for the economic structure; $D_{t}$ is a time-period dummy variable to capture a general market condition at a particular time period; ais the constant andzis the random noise with normal distribution $N(0, \eta)$.

According to model 1a, power consumption in the current period is explained by the lagged real GDP, the lagged electricity price, and the economic structure. In order to control the endogeneity in estimation, we use the lag of those variables except the economic structure, which is considered to be a predetermined variable that is relevant to industrial policy or the context of an economy. Two dummy variables are also added in the function in order to control the time heterogeneity of the estimation for two periods: one for a period from 1980 to 1999, and another from 2000 to 2006, in order to capture the impact of different reform policies on market development. To compare our estimation of China with international experiences, the six OECD countries are also estimated for the same periods from 1980 to 2006. The function is estimated in the logarithm.

Model $1 b-$ demand function with short-run relationship

Modelib attempts to examine the short-run relationship between the power consumption and its explanatory variables. The regression model is specified as follows:

$$
\Delta C_{t}=\alpha+\beta_{1} \Delta G D P_{t-1}+\beta_{2} \Delta p_{t-1}+\beta_{3} \Delta y_{t}+\gamma_{t} D_{t}+\varepsilon_{t}
$$

Model $1 \mathrm{~b}$ uses the first differences of the variables to investigate the short-term relationship. China has liberalized prices for most of industrial and consumer goods since 1992. As a result, we choose the periods from 1992 to 2006 to estimate the model. In order to control the change in China's market environment that was very different between the 1990 s and the 2000s, we employ a time dummy, D, to capture the change in reform policy. Again, estimation is made in the logarithm. 
The second stage is aimed to find out what factors can directly influence the capacity supply in the longterm. According to our derived function of supply capacity, it specifies two basic elements that can affect the supply in the long run: one is demand shocks and another is capacity utilization indicated by the load factor. Empirically, we augment this function by replacing the demand shocks, captured by the variable of power consumption, with its pre-determinants or explanatory variables identified in stage 1, such as GDP, the price of electricity and exports.

Piao and Zhong (2008) argued that the growing shortage of the electricity supply encourages investment into the power generation sector. Kroeber (2008) also pointed the fact that new power plants are built in the industrial areas where the energy demand is high. Their view implies that demand for power consumption should play a direct role in affecting power generation capacity in China. This is consistent with the expectation shown by the function of the capacity growth derived in Box 1:

$\frac{k_{L}}{K_{t-1}}=\left[\frac{q_{l}^{d}}{q_{\mathrm{g}}^{g}}\right]^{\frac{\lambda}{1-\lambda}} \bar{\rho}_{1-\lambda}^{\lambda}$

Where, the capacity growth $\mathrm{K}_{\mathrm{t}} / \mathrm{K}_{\mathrm{t}-1}$ is expected to be driven by the load factor $(\rho)$ and the power demand relative to what the supply can serve $\left(Q^{d} / Q^{s}\right)$. Empirically we replace supply $\left(Q^{s}\right)$ at $t$ with demand at $t-1$, indicating that it will stimulate the growth of capacity when new demand is higher than the previous level. By taking into account a sequence of investment decision and capacity formation, usually taking two or three years to build up a new power plant after the investment starts (Lin, 2004), we write an empirical version of the model (g) as:

$\Delta K_{t}=\alpha+\beta \Delta Q_{t-2}+\theta \bar{\rho}_{t-2}+\epsilon_{t}$

where $\Delta \mathrm{K}$ is the growth of capacity formed at time $\mathrm{t}, \Delta \mathrm{Q}$ is the growth of demand for power consumption that captures the demand shocks occurred at time when the capacity investment decision was made at two year ago of t-2. $\bar{p}_{\mathrm{t}-2}$ is the load factor reported two years ago before new capacity is formed. Empirically, we employ the average load factor of the year in estimation. To replace the power consumption variable with its determinants identified in stage 1 of estimation, such as GDP, the power price and power exports, the equation (2a) becomes

$$
\Delta K_{t}=\alpha+\beta_{1} \Delta G D P_{t-1}+\beta_{2} p_{t-2}+\theta \bar{\rho}_{t-2}+\gamma_{t} D_{t}+\varepsilon_{t}
$$


where the one-year lagged GDP is applied instead of the lagged two years, because this is to mitigate multicollinarity between the GDP and other variables specified in equation $2 b . p$ is the index of the electricity price for the end users.

For the same reason discussed previously, we control the time effect from 1980 to 1990 s and the 2000 s by defining the two time dummy variables in the model. Estimation is made in logarithm.

\subsection{Data}

The variables for regressions include the supply capacity of the power generation (GW), the observed power consumption (GWh), the power exports (GWh), the electricity price index for the end users, the real GDP (billion USD) and the industrial value added (billion USD) at a national level. The aggregated annual data on China, France, Germany, Italy, Japan, the UK and the US over period from 1980 to 2007 are collected from Statistics Yearbook of China published by the State Bureau of Statistics of China, International Energy Agency, UN Data, and World Development Indicators of the World Bank, which gives 27 observations for each country in our sample dataset.

The real GDP of all the seven countries are collected from the online database of the UN Data. The percentage of industrial value added in GDP is obtained from the World Development Indicators in the World Bank online database. For China, we use the percentage of heavy industrial value-added instead. As discussed, the growth of the heavy industrial outputs is highly related to demand for power consumption. Thus, we believe that our estimation will be consistent with the expectation of the positive relationship between the two variables we discussed in section 2 .

The electricity price index of the OECD countries and China are obtained from Electricity Information 2009 and National Bureau of Statistics of China respectively.

The data on the power consumption of all sample countries including China are collected from the online database of Electricity Information 2009 prepared by the International Energy Agency. The data on power supply capacity are collected from the online database of Electricity Information 2009 prepared by the International Energy Agency.

The load factor is calculated by the following formula: (Total Power Output per Year)/(Capacity $\times 24$ Hours $\times 365$ Days). The total power output and the capacity are collected from the online database of the Electricity Information 2009 issued by the International Energy Agency.

The Augmented Dickey-Fuller (ADF) test has been applied to test the stationary concern of the data for both the long-term and short-term time-series variables of each of the seven countries. As shown in Table 5, for China, the power consumption, the real GDP, the electricity price, the capacity and the economic 
structure are non-stationary at the level, but stationary in the difference. Such findings are consistent with the results of the ADF tests in Lam's paper (2004), where the time series of the power consumption and the GDP at the level for China are found to be non-stationary. This justifies OLS as a legitimate approach to estimate the short term relationship of the changes in the power consumption with the real GDP and the electricity prices. In contrast, the load factor is stationary at the level.

As data to the UK, Germany and the US, each country has a similar test result. The same result appears for Italy and Japan except the price that is stationary at the level. France is exceptional since all of the concerning variables are stationary both at the level and in the difference.

\section{RESULTS}

Stage 1: determination of demand for power consumption

GDP

We start our estimation by performing the Granger Causality test first to check the causality relationship between GDP, demand for power consumption and supply capacity. According to Table 6, it suggests that the relationship between demand for power consumption and the GDP growth in China should be bidirectional. This finding reflects a shift of the relationship from the unidirectional causality of electricity consumption to GDP in the past, identified by previous studies (Lin, 2003; Lam, 2004; He, Zhao, Li and Huang, 2006; Yuan, Kang, Zhao and Hu, 2008), to more interaction of the two elements over the recent decades of reform. The bidirectional relationship of demand for energy consumption with GDP is also evident by Mahadevan and Asafu-Adjaye (2007) in study of 20 developed market economies. 
Table 5 The Augmented Dickey-Fuller test for the stationary

\begin{tabular}{|c|c|c|c|c|c|c|c|c|c|c|c|c|c|c|}
\hline & \multicolumn{2}{|c|}{ US } & \multicolumn{2}{|c|}{ Germany } & \multicolumn{2}{|c|}{ Italy } & \multicolumn{2}{|c|}{ UK } & \multicolumn{2}{|c|}{ France } & \multicolumn{2}{|c|}{ Japan } & \multicolumn{2}{|c|}{ China } \\
\hline & Level & $\delta$ & Level & $\delta$ & Level & $\delta$ & Level & $\delta$ & Level & $\delta$ & Level & $\delta$ & Level & $\delta$ \\
\hline Power Consumption & -1.602 & $-5.520 * * *$ & -0.665 & $-3.426 * *$ & -0.040 & $-4.527^{* * *}$ & -0.056 & $4.076 * * *$ & $\frac{-}{3.796 * * *}$ & $-3.334 * *$ & -1.804 & $-4.971 * * *$ & 1.607 & $-2.635^{*}$ \\
\hline Real GDP & -0.117 & $-3.037^{* *}$ & -0.472 & $-3.475^{* *}$ & -1.443 & $-3.485 * *$ & 0.957 & $-2.896^{*}$ & $-3.544^{*}$ & $-4 \cdot 471^{* * *}$ & -1.976 & $-4.138 * * *$ & 0.954 & $-3.275^{* *}$ \\
\hline Electricity Price & -2.106 & $-3.357^{* *}$ & -2.537 & $-2.845^{*}$ & $-3.485^{* *}$ & $-3.818 * *$ & 0.330 & $-5.817 * * *$ & $-2.843^{* *}$ & $2.640^{*}$ & $-4.981 * * *$ & $4.049^{* * *}$ & -1.524 & $-2.801^{*}$ \\
\hline $\begin{array}{l}\text { Percentage of Industrial } \\
\text { Value Added out of GDP }\end{array}$ & -0.550 & $-2.977^{*}$ & -1.049 & $-3.612 * *$ & -1.387 & $-4.711 * * *$ & 0.676 & $-2.946^{*}$ & $-4.273^{* *}$ & $-3.825 * * *$ & 0.023 & $-2.813^{*}$ & -0.082 & $3.950^{* * *}$ \\
\hline Net Capacity & -0.012 & $-3.086 * *$ & -0.887 & $-6.148 * * *$ & -0.045 & $-3.128 * *$ & -0.688 & $-4.135^{* * *}$ & $3.830^{* * *}$ & $-2.305^{* *}$ & -1.877 & $-3.337^{* *}$ & 1.555 & $-2.115^{* *}$ \\
\hline Load Factor & $-1.624 *$ & & $-1.546^{*}$ & & $-3.602^{* *}$ & & $-1.649^{*}$ & & $-4.283^{* *}$ & & $-2.972^{*}$ & & $4.300 * * *$ & \\
\hline
\end{tabular}

Notes: The $\delta$ stands for the first difference. * **, and *** represent the rejection of the null hypothesis of non-stationary at the $10 \%$ level, the $5 \%$ level and the $1 \%$ level. The lag in the Augmented Dickey-Fuller test is selected by the Akaike Information Criterion test. 
Table 6 The Granger Causality Tests

\begin{tabular}{|c|c|c|c|c|c|c|c|}
\hline China & F-Statistic & Prob $>\mathrm{F}$ & Null Hypothesis & & F-Statistic & Prob $>\mathrm{F}$ & Null Hypothesis \\
\hline GDP does not Granger cause Power Consumption & 6.0142 & 0.0069 & Rejected & $\Delta$ GDP does not Granger cause $\Delta$ Capacity & 4.1850 & 0.0244 & Rejected \\
\hline Power Consumption does not Granger cause GDP & 5.1700 & 0.0126 & Rejected & $\Delta$ Capacity does not Granger cause $\Delta$ GDP & 16.2490 & 0.0001 & Rejected \\
\hline$\Delta$ Power Consumption does not Granger cause $\Delta$ Capacity & 5.4790 & 0.0127 & Rejected & Load Factor does not Granger cause $\Delta$ Capacity & 7.1430 & 0.0046 & Rejected \\
\hline$\Delta$ Capacity does not Granger cause $\Delta$ Power Consumption & 0.5004 & 0.6137 & Accepted & $\Delta$ Capacity does not Granger cause Load Factor & 1.3532 & 0.2811 & Accepted \\
\hline US & & & & UK & & & \\
\hline GDP does not Granger cause Power Consumption & 3.5081 & 0.0485 & Rejected & GDP does not Granger cause Power Consumption & 7.1520 & 0.0031 & Rejected \\
\hline Power Consumption does not Granger cause GDP & 6.1459 & 0.0079 & Rejected & Power Consumption does not Granger cause GDP & 1.8301 & 0.1791 & Accepted \\
\hline$\Delta$ GDP does not Granger cause $\Delta$ Capacity & 0.1581 & 0.8548 & Accepted & $\Delta$ GDP does not Granger cause $\Delta$ Capacity & 8.7066 & 0.0016 & Rejected \\
\hline$\Delta$ Capacity does not Granger cause $\Delta$ GDP & 1.8248 & 0.1848 & Accepted & $\Delta$ Capacity does not Granger cause $\Delta$ GDP & 1.5094 & 0.2431 & Accepted \\
\hline Load Factor does not Granger cause $\Delta$ Capacity & $4 \cdot 3020$ & 0.0338 & Rejected & Load Factor does not Granger cause $\Delta$ Capacity & 6.5882 & 0.0057 & Rejected \\
\hline$\Delta$ Capacity does not Granger cause Load Factor & 0.0509 & 0.9978 & Accepted & $\Delta$ Capacity does not Granger cause Load Factor & 10.1310 & 0.0008 & Rejected \\
\hline Germany & & & & France & & & \\
\hline Power Consumption does not Granger cause GDP & 2.5025 & 1.0000 & Accepted & Power Consumption does not Granger cause GDP & 0.1728 & 0.8422 & Accepted \\
\hline$\Delta$ GDP does not Granger cause $\Delta$ Capacity & 2.9887 & 0.0711 & Accepted & $\Delta$ GDP does not Granger cause $\Delta$ Capacity & 1.7075 & 0.2045 & Accepted \\
\hline$\Delta$ Capacity does not Granger cause $\Delta$ GDP & 3.6436 & 0.0430 & Rejected & $\Delta$ Capacity does not Granger cause $\Delta$ GDP & 0.3187 & 0.7304 & Accepted \\
\hline Load Factor does not Granger cause $\Delta$ Capacity & 4.7438 & 0.0085 & Rejected & Load Factor does not Granger cause $\Delta$ Capacity & 3.5748 & 0.0324 & Rejected \\
\hline$\Delta$ Capacity does not Granger cause Load Factor & 2.2834 & 0.0988 & Accepted & $\Delta$ Capacity does not Granger cause Load Factor & 3.3571 & 0.0393 & Rejected \\
\hline Italy & & & & Japan & & & \\
\hline GDP does not Granger cause Power Consumption & 3.4316 & 0.0465 & Rejected & GDP does not Granger cause Power Consumption & 7.4196 & 0.0026 & Rejected \\
\hline Power Consumption does not Granger cause GDP & 2.9784 & 0.0672 & Accepted & Power Consumption does not Granger cause GDP & 1.1730 & 0.3242 & Accepted \\
\hline$\Delta$ GDP does not Granger cause $\Delta$ Capacity & 2.0641 & 0.1508 & Accepted & $\Delta$ GDP does not Granger cause $\Delta$ Capacity & 1.2738 & 0.2996 & Accepted \\
\hline$\Delta$ Capacity does not Granger cause $\Delta \mathrm{GDP}$ & 4.5466 & 0.0220 & Rejected & $\Delta$ Capacity does not Granger cause $\Delta$ GDP & 0.6605 & 0.5265 & Accepted \\
\hline Load Factor does not Granger cause $\Delta$ Capacity & 3.6980 & 0.0413 & Rejected & Load Factor does not Granger cause $\Delta$ Capacity & 3.1720 & 0.0388 & Rejected \\
\hline$\Delta$ Capacity does not Granger cause Load Factor & 8.1709 & 0.0022 & Rejected & $\Delta$ Capacity does not Granger cause Load Factor & 1.4729 & 0.2518 & Accepted \\
\hline
\end{tabular}


Moreover, In Table 6, it also indicates that the changes in the power supply capacity are resulted from the changes in the GDP, demand for power consumption and the load factor respectively in the case of China.

Table 7 presents the estimation of Model $1 \mathrm{a}$ and $1 \mathrm{~b}$. Since the demand for power consumption and GDP is interacted with each other, we place pre-determined GDP in the previous year to explain demand for electric power in the current year. As shown in the Table, the real GDP has a significantly positive impact on demand for power consumption in China. In the long term our estimation identifies $1 \%$ increasing in GDP that would be likely responded by a rise of $0.77 \%$ in demand for power consumption in China. In the short run, $1 \%$ of GDP growth almost could bring up $1 \%$ of demand for power consumption.

Table 7 The estimation results of Model $\mathbf{1 a}$ and $\mathbf{1 b}$

\begin{tabular}{|c|c|c|c|c|c|c|c|}
\hline \multicolumn{8}{|c|}{ A: Model 1a. The long-run determinants of the power consumption (1980 - 2006) } \\
\hline & US & Germany & Italy & UK & France & Japan & China \\
\hline Real GDP(t-1) & $\begin{array}{l}0.7334^{* * *} \\
(8.70)\end{array}$ & $\begin{array}{l}1.300 * * * \\
(6.04)\end{array}$ & $\begin{array}{l}1.403^{* * *} \\
(8.41)\end{array}$ & $\begin{array}{l}0.677^{* * *} \\
(6.49)\end{array}$ & $\begin{array}{l}0.458 \\
(1.47)\end{array}$ & $\begin{array}{l}0.893 * * * \\
(8.76)\end{array}$ & $\begin{array}{l}0.777^{* * *} \\
(31.02)\end{array}$ \\
\hline Electricity Price(t-1) & $\begin{array}{l}-0.195 \\
(-1.50)\end{array}$ & $\begin{array}{l}0.161 \\
(1.45)\end{array}$ & $\begin{array}{l}-0.148 * * \\
(-2.35)\end{array}$ & $\begin{array}{l}-0.209 * * \\
(-2.64)\end{array}$ & $\begin{array}{l}-0.252 \\
(-1.46)\end{array}$ & $\begin{array}{l}-0.162 \\
(-1.50)\end{array}$ & $\begin{array}{c}-0.199 * * * \\
(-4.05)\end{array}$ \\
\hline Economic Structure $\quad(t)$ & $\begin{array}{l}-0.003 \\
(-0.57)\end{array}$ & $\begin{array}{c}0.026^{* * *} \\
(3.99)\end{array}$ & $\begin{array}{l}0.002 \\
(0.35)\end{array}$ & $\begin{array}{l}0.0001 \\
(0.03)\end{array}$ & $\begin{array}{l}-0.036 \\
(-1.49)\end{array}$ & $\begin{array}{l}-0.011 \\
(-0.86)\end{array}$ & $\begin{array}{c}0.038^{* * *} \\
(9.81)\end{array}$ \\
\hline Dummy for 1990 s & $\begin{array}{c}0.049 * * \\
(2.87)\end{array}$ & $\begin{array}{c}-0.113^{* * *} \\
(-3.72)\end{array}$ & $\begin{array}{l}-0.001 \\
(-0.05)\end{array}$ & $\begin{array}{l}0.031^{*} \\
(1.72)\end{array}$ & $\begin{array}{l}0.027 \\
(0.90)\end{array}$ & $\begin{array}{l}0.015 \\
(0.56)\end{array}$ & $\begin{array}{c}0.08 * * \\
(3.10)\end{array}$ \\
\hline Dummy for 2000 s & $\begin{array}{l}0.024 \\
(0.82)\end{array}$ & $\begin{array}{c}-0.107^{* *} \\
(-2.47)\end{array}$ & $\begin{array}{l}0.038 \\
(1.30)\end{array}$ & $\begin{array}{l}0.005 \\
(0.20)\end{array}$ & $\begin{array}{l}-0.012 \\
(-0.21)\end{array}$ & $\begin{array}{l}0.009 \\
(0.26)\end{array}$ & $\begin{array}{l}0.035 \\
(0.80)\end{array}$ \\
\hline Constant & $\begin{array}{l}2.21^{* *} \\
(2.57)\end{array}$ & $\begin{array}{l}-2.99 * * \\
(-2.33)\end{array}$ & $\begin{array}{c}-1.21 \\
(-1.21)\end{array}$ & $\begin{array}{c}2.45 * * * \\
(3.42)\end{array}$ & $\begin{array}{l}4.63^{* *} \\
(2.52)\end{array}$ & $\begin{array}{l}1.69 * \\
(1.84)\end{array}$ & $\begin{array}{c}1.103^{* * *} \\
(5.12)\end{array}$ \\
\hline Adjusted R-square & 0.9917 & 0.8864 & 0.9933 & 0.9858 & 0.9854 & 0.9894 & 0.9978 \\
\hline Observations & 27 & 27 & 27 & 27 & 27 & 27 & 27 \\
\hline ADF Test for the Residuals & $-2.724^{*}$ & $-3.352^{* *}$ & $-5.637^{* * *}$ & $-3.359^{* *}$ & $-3.951^{* * *}$ & $-5.122 * * *$ & $-3.588^{* *}$ \\
\hline
\end{tabular}

B: Model 1b The short-run determinants of the power consumption (1992 - 2006)

\begin{tabular}{|c|c|c|c|c|c|c|c|}
\hline & \multicolumn{7}{|c|}{$\triangle$ Power Consumption (t) } \\
\hline & US & Germany & Italy & UK & France & Japan & China \\
\hline \multirow[t]{2}{*}{$\triangle$ Real GDP $(\mathrm{t}-1)$} & 0.282 & 0.244 & -0.0021 & 0.617 & 0.108 & -0.4117 & $0.934^{* *}$ \\
\hline & $(1.38)$ & $(1.03)$ & $(-0.01)$ & $(1.59)$ & $(0.24)$ & $(-1.26)$ & $(2.48)$ \\
\hline \multirow[t]{2}{*}{$\triangle$ Real Price (t-1) } & $-0.179 * *$ & 0.025 & -0.022 & 0.085 & -0.184 & 0.235 & -0.778 \\
\hline & $(-2.09)$ & $(0.60)$ & $(-0.51)$ & $(0.54)$ & $(-0.96)$ & $(1.39)$ & $(-0.61)$ \\
\hline \multirow[t]{2}{*}{$\triangle$ Economic Structure $\quad(t)$} & 0.006 & $0.0097^{*}$ & 0.0124 & 0.0002 & -0.0052 & 0.0054 & 0.007 \\
\hline & $(0.86)$ & $(1.69)$ & $(0.98)$ & $(0.03)$ & $(-0.29)$ & $(0.58)$ & $(1.43)$ \\
\hline \multirow[t]{2}{*}{ Dummy for 2000 s } & -0.008 & 0.007 & 0.002 & -0.0145 & -0.0013 & -0.016 & $0.049^{* *}$ \\
\hline & $(-1.60)$ & $(1.08)$ & $(0.36)$ & $(-1.35)$ & $(-0.12)$ & $(-1.65)$ & $(2.69)$ \\
\hline \multirow[t]{2}{*}{ Constant } & 0.017 & 0.0054 & $0.026^{* * *}$ & 0.0039 & 0.0128 & $0.032^{* *}$ & -0.02 \\
\hline & $(2.19)$ & $(0.87)$ & $(4.45)$ & $(0.32)$ & $(0.98)$ & $(3.08)$ & $(-0.50)$ \\
\hline Adjusted R-square & 0.455 & 0.2113 & -0.2411 & 0.0115 & -0.2457 & 0.1261 & 0.6050 \\
\hline Observations & 15 & 15 & 15 & 15 & 15 & 15 & 15 \\
\hline \multicolumn{8}{|c|}{$\begin{array}{l}\text { Note: T-statistic significance: * at } 10 \% \text { level, } * * \text { at the } 5 \% \text { level, }{ }^{* * *} \text {, at the } 1 \% \text { level. The lags in the ADF tests of the Model } 1 \text { are } \\
\text { selected by the AIC tests. }\end{array}$} \\
\hline
\end{tabular}


lead to $0.883 \%$ increase in the power consumption. And later on, Wu (2009) also found that a $1 \%$ increase in the real GDP in China would lead to a $0.38 \%$ increase in the power consumption in the long term. Thus, the effect of GDP on power consumption is consistently observed.

For instance, during the first three months of 2009, the growth of the Chinese GDP decreased by $4.5 \%$ points to $6.1 \%$, and the power consumption in China shrank sharply by $4.02 \%$.

In contrast, other six OECD countries also show the positive impact of GDP on the power consumption in the long run, but not in the short run. The coefficients of the GDP of Germany, Italy and Japan are higher than China, which suggests the higher elasticity of power consumption with respect to GDP growth in those three countries in the long run. However, in terms of the short run, it's observed that the GDP of all those six developed countries has no impact on the power consumption, in which this finding is very different from China that has the strong relationship in the short-run. This suggests that, first, China's demand for power consumption is very responsive to changes in GDP, and secondly, the GDP impact on demand for power consumption is generalized internationally across countries for the long run, but the impact is country-specific for the short run, such as only observed in China.

The electricity price

According to the estimation of Model $1 \mathrm{a}$ and $1 \mathrm{~b}$, the end-user price have a negative impact on the power consumption in the long run, but not in the short run both in China and in other OECD countries except the US. On average of all countries, $1 \%$ of increase in the electricity price will lead to around $0.2 \%$ of decrease in demand for consumption. A similar long-term relationship in the case of China was also identified by Lin (2001), but his coefficient was -0.46, higher than our estimated -0.20. The difference may be of different sample data, the data of Lin (2001) is from 1956 to 1994, when compared with our data from 1980 to 2006. For the short run, we found that the price elasticity with respect to consumption is almost inelastic, because China has the rigidity in changing power prices as the electricity price adjustment is a very bureaucratically complicated and politically sensitive issue for the nation. This makes the state to be very cautious in changing the price, in particular, in a large rise. As a result, we can expect that the adjustment of prices will be made small or insignificantly in affecting demand in the short-run.

Again, similar to the impact of GDP on demand for power consumption, the price impact is almost a common phenomenon across the sample countries in the long run, but the impact is country-specific only in the short run.

The economic structure

The variable for the economic structure is measured by the industrial outputs in GDP. According to the results of Model 1a, for China and Germany the structure has the positive impact on the long-run power consumption. Both countries have a large manufacturing sector with stronger exports of manufacturing 
industrial goods. This finding suggests that China needs more power if its economy relies upon the industrial sector more and more. With the Chinese data from 1952 to 2001, Lin (2003) found the similar results that the gross output of the light industries has negative relationship with the power consumption in the long run. Wu (2009) studied the cross-sectional data from 30 Chinese provinces in 2005, and also found that the proportion of the industrial sector in GDP has a positive impact upon the regional electric power consumption, which is consistent with our finding.

In contrast to China, the long run impact of the structure does not appear in every OECD sample country. This sharp contrast reflects that the Chinese economic development relies upon the energy-intensive industrial sector more and more over the past 30 years. For instance, from 2000 to 2007, the production of ethylene, cement and steel, which are heavy energy-consuming products, has increased by $136.28 \%, 137.55 \%$ and $293.76 \%$ respectively in China. The heavy industry has taken up the major part of the industrial sector in China, of which the proportion keeps on growing over the time. Just as described previously, the heavy industries in China produced $58.03 \%$ of the total industrial outputs in 1999, and such figure increased to $70.47 \%$ in 2007 . And, the percentage of the whole industrial sector out of the GDP in China is still growing in recent years, i.e. from $45.9 \%$ in 2000 to $48.5 \%$ in 2007 .

Under such economic development, China needs more and more consumption of energy. From 2000 to 2007, the energy consumed in China for producing the ethylene, the cement and the steel all increased by over $90 \%$. In 2007 , the Chinese heavy industry consumed about $91 \%$ of the energy and about $89 \%$ of the electricity supplied to all industrial sectors. Eventually, in the same year, the Chinese industrial sector consumed around $71 \%$ of the total energy and around $75 \%$ of the total power supplied for the whole country. He and Zhang (2005) hold the similar understanding and argue that the main reason for the recent rise in the energy-intensity could be due to the growth of the proportion of the heavy-industries out of the GDP in China.

The time dummies

According to the results of the Model $1 \mathrm{~b}$, the time dummy for the 2000 s has a positive relationship with demand for power consumption. This means that the growth of demand for consumption in China was further accelerated in the 2000s, which would be caused by the further reform of the power sector. By 2002, the Chinese power industry has been restructured from the single and vertically integrated mechanism, which stimulated the vigorous capacity expansion and production (Varley, 2006). 
Table.8 Estimation Results of Model 2

\begin{tabular}{|c|c|c|c|c|}
\hline \multicolumn{5}{|c|}{ A: The estimation results of the supply capacity model for China } \\
\hline & Model $2 a$ & Model 2b & Model 2a & Model 2b \\
\hline & ACoparitr: & ACapadiy & $\Delta$ Copacts: & ACapadity \\
\hline AFower Conswmphoni-a & $\begin{array}{l}\begin{array}{l}0.2011^{* *} \\
(1.97)\end{array}\end{array}$ & & $\begin{array}{c}0.1966^{*} \\
(1.88)\end{array}$ & \\
\hline$\triangle G D P_{\mathrm{n}-\mathrm{a}}$ & & $\begin{array}{c}0.1703^{*} \\
(1.67)\end{array}$ & & $\begin{array}{c}0.1864^{*} \\
(1.79)\end{array}$ \\
\hline Eond Fantor & $\begin{array}{l}0.5147^{* *} \\
(6.87)\end{array}$ & $\begin{array}{c}0.5891 * * * \\
(9.96)\end{array}$ & $\begin{array}{r}0.5117^{* * *} \\
(6.66)\end{array}$ & $\begin{array}{r}0.5759^{* * *} \\
(9.90)\end{array}$ \\
\hline Elactrieity Frice & & & $\begin{array}{c}-0.0084 \\
(0.4)\end{array}$ & $\begin{array}{r}-0.0194 \\
(0.9)\end{array}$ \\
\hline \multirow[t]{2}{*}{ Dwmmy } & $0.0124 * *$ & $0.0180 * * *$ & $0.0127^{*}$ & $0.0186^{* * *}$ \\
\hline & $(1.96)$ & $(2.97)$ & $(1.95)$ & $(3.03)$ \\
\hline \multirow[t]{2}{*}{ Dummy: } & $0.0409 * * *$ & $0.0517^{* * *}$ & $0.0445^{* * *}$ & $0.0597^{* * *}$ \\
\hline & $(5.00)$ & $(7.48)$ & $(3.60)$ & $(5.29)$ \\
\hline \multirow[t]{2}{*}{ Constant } & $-2.3221 * * *$ & $-2.6701 * * *$ & $-2.2673^{* * *}$ & -2.5178 \\
\hline & $(-6.77)$ & $(-9.45)$ & $(-6.03)$ & $(-7,62)$ \\
\hline$E^{2}$ & 0.8637 & 0.8573 & 0.8648 & 0.8628 \\
\hline$A d j E^{2}$ & 0.8378 & 0.8301 & 0.8310 & 0.8286 \\
\hline Observations & 26 & 26 & 26 & 26 \\
\hline
\end{tabular}

B: Estimation results of the supply capacity model for selected OECD countries

\begin{tabular}{|c|c|c|c|c|c|c|}
\hline & US & Germany & Italy & UK & France & Japan \\
\hline & ACapadty & ACapadty: & ACapedity & $\Delta C$ apndty & ACapadty & DCapacty \\
\hline \multirow[t]{2}{*}{$\triangle G D P_{\mathrm{n}-\mathrm{A}}$} & -0.1483 & 0.2546 & -0.2550 & $0.6339^{* *}$ & 0.2586 & 0.0275 \\
\hline & $(-0.60)$ & $(0.50)$ & $(-1.13)$ & $(2.00)$ & $(0.63)$ & $(0.23)$ \\
\hline \multirow[t]{2}{*}{ Load Factort-z } & $0.1969 * * *$ & $0.4468 * * *$ & $0.2120 * * *$ & $0.2880 * *$ & $0.2342^{*}$ & $0.1229 *$ \\
\hline & $(2.58)$ & $(3.23)$ & $(3.38)$ & $(2.28)$ & $(1.74)$ & $(1.94)$ \\
\hline \multirow[t]{2}{*}{$\Delta$ Electricity Price $e_{-1}$} & 0.1283 & 0.1156 & -0.0456 & $0.2095 * *$ & $0.2729^{*}$ & $0.0737^{* *}$ \\
\hline & $(0.96)$ & $(0.96)$ & $(-1.16)$ & $(2.06)$ & $(1.81)$ & $(2.35)$ \\
\hline \multirow[t]{2}{*}{ Dummy } & $-0.0366 * * *$ & $0.0576^{* *}$ & -0.0014 & -0.0257 & $-0.0632 * * *$ & -0.0049 \\
\hline & $(-2.48)$ & $(2.33)$ & $(-0.20)$ & $(-1.52)$ & $(-3.41)$ & $(-0.76)$ \\
\hline \multirow[t]{2}{*}{ Dummys } & -0.0022 & $0.0662 * * *$ & -0.0010 & $-0.0425^{*}$ & $-0.0958 * * *$ & $-0.1414 * * *$ \\
\hline & $(-0.15)$ & $(2.74)$ & $(-0.12)$ & $(-1.82)$ & $(-3.30)$ & $(-2.92)$ \\
\hline \multirow[t]{2}{*}{ Constant } & $-0.8600 * *$ & $-2.042^{* * *}$ & -0.9360 & $-1.3271^{* *}$ & $-2.2369 * * *$ & $-0.8681^{* * * *}$ \\
\hline & $(-2.52)$ & $(-3.24)$ & $(-3.26)$ & $(-2.32)$ & $(-2.38)$ & $(-2.76)$ \\
\hline$E^{2}$ & 0.4721 & 0.4260 & 0.4286 & 0.6019 & 0.6168 & 0.6596 \\
\hline$A d j R^{2}$ & 0.3463 & 0.2893 & 0.2926 & 0.5072 & 0.5256 & 0.5822 \\
\hline Observations & 28 & 28 & 27 & 27 & 27 & 28 \\
\hline
\end{tabular}


Stage 2: Determination of supply of capacity

\section{Demand for power consumption}

Having investigated what determines demand for power consumption in Table 7, we turn to discuss what determines the capacity of supply. In Table 8, as expected by theory of demand responded by supply, the demand shocks have a significant impact on capacity in the long run, evident by the Chinese case. For instance, $1 \%$ increase in power consumption would lead to some $0.2 \%$ increase in capacity two years after in China. This result is consistent when we replace the consumption variable with GDP in the estimation, in which GDP shows a direct impact both on demand for consumption and on supply capacity. However, in contrast, the significantly positive impact of GDP on capacity of supply cannot be directly observed for OECD countries except the UK.

One explanation for China to have a significant response of capacity to GDP is because manufacturing industrial outputs dominate almost 50\% of the Chinese GDP as pointed out in the discussion of the section 2. The manufacturing industry also consumes more than $75 \%$ of total of electric power produced in China, see Table 3. The industrial dominance of GDP at such high level is unique when compared with other OECD countries.

China is responsive to demand shocks by promoting capacity expansion through liberalizing power generation market but the responsiveness is not high. $1 \%$ growth in demand only brings up $0.2 \%$ growth in supply capacity. The inelasticity of capacity with respect to GDP can be explained by two reasons. One is of replacement investment, which replaces small power plants with big ones. Another is rapid investment on power generation capacity that has created capacity surplus at an aggregate level, in which the surplus can absorb excessive demand to some extent.

For the replacement effect, China promotes the replacement of small power plants with large ones via new investment. This replacement creates productive efficiency gains for given capacity, since the big is more efficient than the small. The efficiency gains means higher productivity and so more outputs that can be produced in using the same amount of capacity. This enables $1 \%$ growth of new capacity to server more than $1 \%$ growth of demand. The extra capacity gained from using more efficient electric generating facilities could be significant at an aggregate level for China since more than 90\% of power firms are small, see Table 9.

For the surplus effect on use of capacity, it is obvious. Table 10 shows that there is some $50 \%$ of capacity that have not been utilized, which helps absorb excess demand shocks. As a result, this weakens the responses of capacity to changes in GDP. 
Table 9 The large power plants with more than 1000MW capacity in the UK and China

\begin{tabular}{lrrrr} 
& \multicolumn{2}{c}{2005} & \multicolumn{2}{c}{2008} \\
& Number & Capacity (MW) & Number & Capacity (MW) \\
\cline { 2 - 5 } The UK & & & & \\
Plants > 1000 MW & 30 & 48,251 & 31 & 49,130 \\
Total & 264 & 77,504 & 320 & 78,293 \\
Per cent & $11.36 \%$ & $62.26 \%$ & $9.69 \%$ & $62.75 \%$ \\
\hline China & & & & \\
Plants > 1000 MW & 129 & 192,930 & & \\
Total & 3,078 & 508,410 & & \\
Per cent & $4.19 \%$ & $37.95 \%$ & & \\
\hline
\end{tabular}

Source: Digest of United Kingdom energy statistics 2006 \& 2009, Department of Energy \& Climate Change of the UK, Table 8; National Bureau of Statistics of China; China Electric Power Yearbook 2006; “Annual Report of Power Industry in China 2008", China Economic Information Network, pp. 75

Table 10 The Surplus Power Capacity in China and the UK in 2008

\begin{tabular}{|c|c|c|c|}
\hline & $\%$ out of total capacity & Load factor & $\begin{array}{c}\text { Thermal efficiency } \\
\text { (gross calorific value basis) }\end{array}$ \\
\hline & $\%$ & $\%$ & $\%$ \\
\hline \multicolumn{4}{|l|}{ UK } \\
\hline Combined cycle gas turbine stations & 34.66 & 69.3 & 51.9 \\
\hline Coal fired stations & 30.26 & 40.5 & 36 \\
\hline Nuclear stations & 14.36 & 49.4 & 37.9 \\
\hline Overall & 100 & 55.71 & 42.7 \\
\hline \multicolumn{4}{|l|}{ China } \\
\hline Combined cycle gas turbine stations & 0 & 0 & NA \\
\hline Coal fired stations & 77.15 & 51.2 & NA \\
\hline Nuclear stations & 2.27 & 56.7 & NA \\
\hline Overall & 100 & 51.74 & 35.21 \\
\hline
\end{tabular}

Source: The UK data are collected from the Department of Energy \& Climate Change of the UK; The Chinese data are collected from the National Bureau of Statistics of China.

Obviously, GDP growth as a direct effect on supply capacity is a country-specific phenomenon, such as China and the UK, but others do not have such the direct impact, GDP can only influence supply indirectly through affecting demand for power consumption.

The load factor

In contrast, as predicted by our theory of the capacity function, the load factor is surprisingly strong across all of our sample countries including China. The average load factor of an economy implies a state of demand for power since the higher load factor implies the higher demand for consumption of electricity. Apparently, the load factor as a strong driving force to capacity expansion appears in every sample country, which is an internationally generalized or non-country-specific phenomenon. The capacity is very responsive to the change in the factor. For instance, in China, $1 \%$ increase in the factor can be responded by 
$0.59 \%$ growth of capacity. For OECD countries, the elasticity of capacity with respect to the factor is around 0.2 .

The significant impact of the load factor on the capacity of supply suggests that a power industry does respond to the change in demand through the consumption impact on the capacity utilization of the industry. The industry is unlikely responding directly to GDP growth in adjusting its long run supply, except China and the UK. However, the industry is likely to respond to the change in demand relative to the utilization of the capacity. Apparently, as long as growth of demand for power improves the utilization, then the industry responds to demand. The impact of demand on capacity relative to the utilization of existing capacity is a distinctive finding from existing studies on the relationship of power supply with demand.

The electricity price

In general, an increase in the price of electricity shall be responded by the firm positively to produce more by expanding its capacity in the long run. This expectation is evident by Germany, France and Japan, but not in other economies. The evidence may imply that electricity markets in these countries are vertically integrated as the end user price and the power producer's sale price are consistently co-moved. France is an example of the vertical integration. If the power generation market and the trade market are separated, or less integrated, it is likely that a change in the end user price will not be responded by the power producers, for example of China. On this basis, we argue that the price impact on capacity is countryspecific. This suggests that using the price as a policy instrument to promote the growth of power supply in the long run is likely to be in question unless it is evident that the industry responds to prices.

Another possible explanation to the failure of the price in affecting the long run supply in some OECD regions is a result of the power market horizontal integration. A rise in the price in one region could be responded by more supply from other regions where exports more competitive electricity, and therefore the local supply will become a loser. For instance, Italy imported $16 \%$ of total electricity consumption from other EU countries in 2007 and it is expected that the imports could further increase to substitute domestic supply if the price continues arising.

In China, the interpretation to failure of electricity prices in affecting supply is due to the vertical disintegration between the selling prices given to the power firms and the end-user prices that we employed for estimation. A change in the end-user price will not affect power firms but the Grid, since Chinese power firms only sell their power to the Grid at a planned price. The re-selling price of power by the Grid to the end-users does not affect the benefits of upstream power firms. As a result, the vertical disintegration limits a role of electricity prices paid by the end-users in affecting supply in the long run. However, this does not mean that the price cannot affect supply at all. What we argue is that in the vertical 
disintegration the impact of the end-user price on supply capacity is not direct but indirect through affecting demand for power to supply.

\section{CONCLUSIONS}

This paper employs the two-stage estimation to investigate the direct and indirect determinants to the capacity of electricity supply in China, with reference to the OECD countries. In the first stage, we tested both the long-run and short-run determinants of the power consumption, and obtained three interesting findings.

First, GDP growth has both the long-run and short-run impact on demand for power consumption in China. In terms of the OECD, this positive relationship can also be observed in the long run. The impact of GDP on demand for electric power is generalized phenomena across all of sample countries. This argument differs from an existing view that the power demand caused GDP growth in China.

Secondly, the structure of the Chinese economy affects demand for power. This is because China faces a rapid growth of heavy industry in the economy, which drives up demand for power. Both China and Germany are a large manufacturing and industry-good-exporting country, which explains partly why both countries have the industrial structure impact on the power demand. It is evident that the industry structure impact is country-specific phenomena.

Thirdly, prices for the end-users reduce demand for power. This is evident for China, the US, the UK, Japan and Italy, but not particularly stronger in Germany and France. France exports electricity at a lowest electricity price on average in EU, even lower than China. This may explains why prices cannot affect demand significantly. On the basis of our evidence, in general, we argue that the impact of prices on demand for power is a non-country specific effect.

Can GDP, which drives demand for power, and prices also affect supply directly? In the second stage of our estimation, the question is investigated, which helps develop the following views. First, demand for power consumption determines directly the capacity of supply, and this is evident in China. Secondly, if we replace the power demand with GDP, then the GDP impact on the capacity of supply is not strongly identified empirically except China and the UK. This indicates that the power industry does not respond directly to growth of GDP in choosing their investment in capacity. However, this does not mean that GDP cannot affect power supply. GDP affects supply capacity indirectly through affecting demand for power. Thirdly, the most direct impact on capacity is the load factor, in which this evidence is surprisingly stronger in explaining capacity for every economy in our estimation. This is generalized or non-country specific phenomena, and consistent with the theory of capacity function developed by this study. 
In contrast, the effect of prices on capacity is very weak. There are two possible explanations to the phenomena. One is less vertical integration in electric markets that separate the firm sales price from the end-user price. Another is due to market horizontal integration in the EU that creates competition for supply among regions in the EU. China is an example of the vertical disintegration in the electric market. That is to say, the Chinese power generation industry does not respond directly to prices paid by the endusers in choosing its capacity for supply. As a result, the end-user price does not affect capacity directly but indirectly through its impact on demand.

Given the open entry to the electric power generation market and the rapid growth of investment on power generation capacity in China, will this create massive surplus of the power generating capacity in the foreseeable future? The implication of this study to the question is unlikely since the growth of the capacity is highly geared with the utilization rate of the existing capacity unless there is an unexpected large fall in demand. In short, the capacity growth is driven by demand relative to the use of existing capacity.

\section{REFERENCES}

Borenstein, S.; Bushinell, J. "An Empirical Analysis of the Potential for Market Power in California's Electricity Industry”, J Ind Econ, 1999: 47: 285-323.

Botterud, A.; Korpas, M., "A Stochastic Dynamic Model for Optimal Timing of Investments in New Generation Capacity in Restructured Power Systems", International Journal of Electrical Power \& Energy Systems, 2007: 29: 163-174.

Cromption, P.l; Wu, Y., "Energy Consumption in China: Past Trends and Future Directions", Energ Econ, 2005: 27: 195-208.

Fleten, S.E.; Maribu, K.M.; Wangensteen, I., "Optimal Investment Strategies in Decentralised Renewable Power Generation under Uncertainty", Energy, 2007: 32: 803-815.

Garbaccio, R. F.; Ho, M. S.; Jorgenson, D. W., "Why has the Energy-Output Ratio Fallen in China?", discussion paper, 1999. http://www.hks.harvard.edu/m-rcbg/ptep/energy-ratio.pdf

Gollier, C.; Proult, D.; Thais, F.; Walgenwitz, G., "Choice of Nuclear Power Investments under Price Uncertainty: Valuing Modularity”, Energ Econ, 2005: 27: 667-685.

He, Y.; Zhao, S.; Li, Y.; Huang, W., "The Study of the Relationship between Power Industry and Growth in China", Ind Econ Research, 2006: 1: 47-53, Beijing.

Kroeber, A., "Enigma Variations: Unwrapping the Riddle of China's Electricity Industry", Dragonomics, 2008, discussion paper, http://www.gavekal.com/

Lam, P., “Pricing of Electricity in China”, Energy, 2004: 29: 287-300.

Li, B.; Dorian, J., "Change in China's Power Sector", Energ Policy, 1995: 23: 619-626. 
Liao, H.; Fan, Y.; Wei, Y., “What induced China's Energy Intensity to Fluctuate: 1997-2006?”, Energ Policy, 2007: 35: 4640-4649.

Lin, B., “The Econometric Research on Energy Demands of China”, Stat Research, 2001: 10: 34-39. Beijing

Lin, B., "The Power Consumption and Chinese Economic Growth on the Basis of Investigation on the Function of Productivity", Management World, 2003: 11: 18-27. Beijing

Lin, B., “Power Shortage, Short-run Response, and Long-run Consideration”, Econ Research, 2004: 3: 28-36. Beijing

Ma, H.; Oxley, L.; Gibson, J., “China's Energy Situation in the New Millennium”, Ren Sust Energ Rev, 2009: 13: 1781-1799.

Mahadevan, R.; Asafu-Adjaye, J., "Energy Consumption, Economic Growth and Prices: A Reassessment using Panel VECM for Developed and Developing Countries”, Energ Policy, 2007: 35: 2481-2490.

Piao G.; Zhang, F., “Building a Clean and Efficient Power System”, Annual Report on China's Energ Dev, ISBN 978-7-5097-0090-7, 2008:.210-256.

Rosen, D. H.; House, T., “China Energy: A Guide for the Perplexed”, China Balance Sheet, 2007, discussion paper, http://www.iie.com/publications/papers/rosen0507.pdf

Shiu, A.; Lam, P., “Electricity Consumption and Economic Growth in China”, Energ Policy, 2004: 32: 47-54.

Suzuki, A.; Takizawa, S., "Analysis of the Decision to Invest for Constructing a Nuclear Power Plant under Regulation of Electricity Price", Decision Support Systems, 2004: 37: 449-456.

Tishler, A.; Milstein, I.; Woo, C., "Capacity Commitment and Price Volatility in a Competitive Electricity Market”, Energy Economics, 2008: 30: 1625-1647.

Varley, C. (2006), “Towards More Efficient Pricing and Investment in China's Power Sector”, Energ Prices \& Taxes,2006: 3: 11-20.

Wen, F.S.; Wu, Felix F.; Ni, Y.X., "Generation Capacity Adequacy in the Competitive Electricity Market Environment”, Electrical Power and Energy System, 2004: 26: 365-372. Beijing

Wolak, F. A.; Patrick, R. H., "The Impact of Market Rules and Market Structure on the Price Determination Process in the England and Wales Electricity Market", 1996, discussion paper, http://www.nber.org/papers/w8248.pdf

Wu, K.; Li, Binsheng, “Energy Development in China: National Policies and Regional Strategies”, Energ Policy, 1995: 23:167-178.

Wu, Y., "Positive Study on Determinants of Regional Electric Power Consumption”, Econ Geogr, 2009: 29: 1318-1321.

Yang, H.; Zhang, M., "Analysis of Impact of Energy-intensive Products Export on China's Energy and Environment”, China Energy, 2007: 29: 26-44. Beijing

Yuan, J.; Kang, J.; Zhao, C.; Hu, Z., "Energy Consumption and Economic Growth: Evidence from China at both Aggregated and Disaggregated Levels”, Energ Econ,2008: 30: 3077-3094.

Zhang, Y.; Nie, R., “Correlativity Analysis of Energy Consumption and Industrial Structure Change”, Energ Research \& Utilisation, 2005: 5: 9-12.

Zhang, Y.; Sun, H., “A Study on China's Energy Consumption Error Correction Model: An Empirical Analysis Based on Heavy Industrial Structure”, J China Pop, Resour Environ, 2008: 18: pp. 74-78. 


\section{Appendix BOX 1 Derivation of the Function of Power Supply Capacity}

At an aggregate level, suppose we observe an actual capacity $\mathrm{K}$ that equals to the equilibrium capacity $\mathrm{K}^{*}$ at time $\mathrm{t}$. The current $\mathrm{K}$ at $\mathrm{t}$ grows from the previous level of $\mathrm{K}$ at $\mathrm{t}-1$. Therefore, either $\mathrm{K}$ can grow from the past to the equilibrium level of $\mathrm{K}^{*}$ at $\mathrm{t}$, or $\mathrm{K}$ can grow to a new level that diverts from the equilibrium. This growing process can be described by the adjustment function as follows:

$$
K_{t}=\left[\frac{R_{r}^{*}}{R_{t-1}}\right]^{\lambda} K_{t-1}
$$

where $\lambda$ is the growing-adjustment coefficient. $\lambda=1, \mathrm{~K}$ is grown to a level where $\mathrm{K}=\mathrm{K}^{*} . \lambda=0, \mathrm{~K}$ remains as same as the past, $\mathrm{K}_{\mathrm{t}}=\mathrm{K}_{\mathrm{t}-1}$. When $0<\lambda<1$, then $\mathrm{K}$ grows from the past to a new level that diverts from the equilibrium. At the $\mathrm{K}^{*}$, the equilibrium means that supply of power outputs $Q^{s}$ equals to demand for power $Q^{d}$. When the utilization of the capacity is taken into account, we can write $Q^{s}$ as $\rho \mathrm{K}^{*}$, where $\rho$ is a load factor that measures how much production capacity has been utilized to produce $\mathrm{Q}^{\mathrm{s}}$. This gives

$$
Q^{z}=Q^{d} \text { or } \quad p K^{*}=Q^{d}
$$

Since the load factor can be defined as $=\frac{Q^{S}}{\bar{g} R}$, where $\bar{\rho}$ is the maximal capacity utilization or the maximal load factor feasibly allowed by technique. $\bar{p}$ is less than $100 \%$ since a power firm must retain some capacity reserves from the management perspective of the technique safety. We call $\bar{p}$ as the technically feasible load factor. The manipulation of $\rho \mathrm{K}^{*}=\mathrm{Q}^{\mathrm{d}}$ and $\rho=\frac{Q^{5}}{p^{*}}$ provides us with

$$
K^{*}=\frac{\varphi^{x}}{q^{x}} \bar{p} K
$$

$$
\begin{aligned}
& \text { Substituting (c) to (a) gets } \quad K_{\mathrm{t}}=\left[\frac{q_{t}^{d}}{q_{t}^{z}}\right]^{\lambda} \bar{\rho}^{\dot{\lambda}} K_{t}^{\alpha} K_{t-1}^{1} \\
& \text { This means } \\
& \text { By manipulating (e) gives } \\
& X_{z}^{1-\lambda}=\left[\frac{q_{F}^{1}}{q_{t}^{1}}\right]^{\lambda} \bar{\rho}^{\lambda} K_{t-1}^{1-\lambda} \\
& K_{t}=\left[\frac{q_{t}^{d}}{q_{r}^{z}}\right]^{\frac{\lambda}{1-\lambda}} \frac{\lambda}{\rho^{1-\lambda}} K_{t-1} \\
& \frac{R_{s}}{R_{r-1}}=\left[\frac{q_{r}^{a}}{q_{r}^{2}}\right]^{\frac{\lambda}{i-\lambda}} \bar{\rho}^{\frac{\lambda}{1-\lambda}}
\end{aligned}
$$

Apparently, the growth of capacity $\mathrm{K}_{\mathrm{t}} / \mathrm{K}_{\mathrm{t}-1}$ is expected to be driven by the load factor and the power demand relative to the supply. The demand shocks to the supply are indicated by $Q^{d} / Q^{s}$. If the demand shock $Q^{d}$ is greater than what supply $\mathrm{Q}^{\mathrm{d}}$ can server, then $\mathrm{Q}^{\mathrm{d}} / \mathrm{Q}^{\mathrm{s}}>1$, which promotes capacity to grow more; if the demand shock can be served by $Q^{s}$, then $Q^{d} / Q^{s}<1$, which discourages capacity to grow. For the same analogy, any increase in the load factor will be expected to be responded by capacity positively. 